This is the Author Accepted Manuscript of a paper due to appear in Disability and Rehabilitation (accepted February 2017)

\title{
People with Intellectual Disabilities and Dysphagia
}

Janet Robertson $^{1}$, Darren Chadwick ${ }^{2}$, Susannah Baines ${ }^{1}$, Eric Emerson ${ }^{1,3}$ and Chris Hatton ${ }^{1}$

${ }^{1}$ Centre for Disability Research, Division of Health Research, Faculty of Health and Medicine, Lancaster University, Lancaster, United Kingdom

${ }^{2}$ Faculty of Education, Health \& Wellbeing, University of Wolverhampton, Wolverhampton, United Kingdom

${ }^{3}$ Centre for Disability Research and Policy, University of Sydney, Sydney, Australia

Corresponding Author: Janet Robertson, Centre for Disability Research, Division of Health Research, Faculty of Health and Medicine, Lancaster University, LA1 4YG, United Kingdom. Email: j.m.robertson@lancaster.ac.uk Tel: +44 1524592895 Fax: +44 1524 592658

Funding information: This work was supported by Public Health England. However, the findings and views reported in this paper are those of the authors and should not be attributed to Public Health England.

Declaration of interest: The authors report no declarations of interest. 


\title{
People with Intellectual Disabilities and Dysphagia
}

\begin{abstract}
Purpose. Dysphagia (difficulties in eating, drinking or swallowing) is associated with serious health complications and psychosocial sequelae. This review aims to summarise the state of the evidence regarding dysphagia in people with intellectual disabilities (excluding prevalence), identify gaps in the evidence base and highlight future research priorities.
\end{abstract}

Method. Studies published from $1^{\text {st }}$ January 1990 to $19^{\text {th }}$ July 2016 were identified using Medline, Cinahl, PsycINFO, Web of Science, email requests, and cross-citations. Studies were reviewed narratively in relation to identified themes.

Results. A total of 35 studies were included in the review. Themes identified were: health conditions associated with dysphagia; mortality; health service use; practice and knowledge in supporting people with intellectual disabilities and dysphagia; intervention effectiveness; and quality of life. Dysphagia is associated with respiratory infections and choking, and may be under-recognised. Silent aspiration is common and may go unnoticed. Management practices exist but there are few intervention studies and no RCTs, hence the effectiveness of these is currently unclear.

Conclusion. Dysphagia is a key concern in relation to people with intellectual disabilities. There is urgent need for research on the management of dysphagia in people with intellectual disabilities, including mealtime support offered, positioning, dietary modification and impact on wellbeing.

Keywords: dysphagia; intellectual disabilities; review 


\section{Introduction}

Dysphagia (difficulties in eating, drinking and swallowing) is associated with many health complications. Aspiration pneumonia is considered by many to be the main complication of dysphagia and is of significant concern due to its link with subsequent morbidity and mortality in people with intellectual disabilities $[1,2,3,4]$. Other health complications include choking and airway blockage $[5,6,7]$ and compromised nutritional status and dehydration $[8,9,10,11,12]$. In addition, urinary tract infections, headaches, constipation, oesophagitis and reduced ability to combat infections have all been associated with dysphagia $[13,14,15]$.

In addition to health complications, the psychosocial impacts of dysphagia include loss of opportunity for communication during meals, increased stigma when eating in community settings and loss of dignity associated with being supported to eat and drink $[16,17]$. Further, reduced choice may occur alongside a managed eating and drinking regime, with an associated loss of enjoyment of meals and drinks due to dietary modification (e.g. thickening drinks, mashed food and food exclusions) reducing individual quality of life and wellbeing. Tension often exists between quality of life concerns and the need for safer eating and drinking strategies [e.g. 16, 17, 18, 19, 20, 21].

Intellectual disability is a risk factor for dysphagia, with increased likelihood of dysphagia occurring with increasing severity of cognitive impairment $[22,23]$. The association between dysphagia, its complications, and mortality appears pronounced in people with intellectual disabilities. Respiratory disease, particularly bronchopneumonia, is a leading cause of death in people with intellectual disabilities, in particular in those with profound intellectual and 
multiple disabilities, accounting for significantly more deaths than in the local general population $[1,24]$. Preventable lung inflammation caused by solids or liquids, and foreign bodies has also been associated with mortality in people with intellectual disabilities [25]. The importance of dysphagia in relation to the well-being of people with intellectual disabilities led the United Kingdom National Patient Safety Agency (NPSA) to identify swallowing difficulties as one of five priority areas in relation to safety risks for people with intellectual disabilities using healthcare services [26] and there has been a call for research investigating mealtime safety incidents involving people with intellectual and developmental disabilities [27].

In addition, the issue of dysphagia in people with intellectual disabilities may be complicated by medical co-morbidities, psychiatric, communicative, cognitive and behavioural issues. For example, there is a link between the side-effects of neuroleptic medications and dysphagia [28] and people with intellectual disabilities are more likely than others to be prescribed these [e.g. anti-psychotic medication, 29]. Further, specific syndromes associated with intellectual disabilities can result in both anatomical and neurological precursors for dysphagia, including Down Syndrome [30, 31], Rubinstein Taybi Syndrome [32], and Rett Syndrome $[33,34]$. Behavioural factors which may be an issue for people with intellectual disabilities such as pica, cramming food and eating and drinking quickly may also exacerbate dysphagia symptoms $[6,35]$. Intellectual disability may also impact on the ability to learn compensatory strategies and retain skills [36]. Finally, some people with intellectual disabilities may be unable to communicate their dysphagia related experiences [cf. 37].

While these issues indicate the importance of considering dysphagia specifically in relation to people who have intellectual disabilities, systematic reviews concerning dysphagia research 
have not substantively reported on research investigating dysphagia in people with intellectual disabilities [38]. In this review, we summarise existing research evidence regarding dysphagia which clearly relates to people with intellectual disabilities, to identify the state of the evidence, identify gaps in the evidence base and highlight future research priorities. The review aims to identify comprehensive themes in the research evidence base relating to the nature of dysphagia and the management of dysphagia in people with intellectual disabilities. This issue of the prevalence of dysphagia in people with intellectual disabilities is covered in a separate review [39].

\section{Method}

A narrative review was performed as these are suited to comprehensive topics [40] but elements of the systematic review process (with the exception of the assessment of study quality) were used to strengthen the process as suggested by Collins and Fauser (2005) [39].

\section{Identifying relevant studies}

Electronic literature database searches were conducted in Medline, Cinahl and PsycINFO (all on EBSCO) and Web of Science (SCI-EXPANDED, SSCI and A\&HCI) in June 2015 and subsequently updated on $19^{\text {th }}$ July 2016. Searches combined terms for dysphagia and intellectual disabilities with the Boolean operator 'and'. An example of database specific search terms (Medline) is given in Appendix One. Reference lists of studies meeting inclusion criteria were searched and in June 2015 a request for information was sent to members of the International Association for the Scientific Study of Intellectual and Developmental Disabilities (IASSIDD) Health Special Interest Research Group and the Intellectual Disability UK Research mailing list, with the request also published in the TAC Bulletin in October 2015 (www.teamaroundthechild.com). 


\section{Study selection}

\section{Inclusion Criteria}

Studies were required to meet all the following criteria:

- Peer reviewed

- English language full text

- Published between 1990 and 2016

- Primary research, service audit or evaluation

- Samples of people with intellectual disabilities, or samples of e.g. people with cerebral palsy where at least $50 \%$ of the sample are explicitly noted to have intellectual disabilities, or mixed samples where results are disaggregated for people with intellectual disabilities (for $\%$ of sample relating to intellectual disabilities in each study see Table 1).

In addition, studies had to meet one of the following criteria:

- Study regarding the epidemiology of dysphagia

- Study regarding health risks or quality of life issues associated with dysphagia

- Study of interventions aiming to improve knowledge or practice in relation to dysphagia management

- Study of current knowledge or practice in relation to dysphagia management

- Study on the views of people with intellectual disabilities, professionals, carers or family with regard to dysphagia

- Study considering factors associated with outcomes for people with intellectual disabilities and dysphagia.

\section{Exclusion Criteria}

- Not peer reviewed or where peer review status unclear 
- Reviews, letters, commentaries, editorials, meeting or conference abstracts

- Case studies or case series with five or fewer participants

- Only includes information relating to specific syndromes e.g. Rett syndrome (with the exception of Down syndrome which is the most common genetic cause of intellectual disabilities [41])

- Conditions where intellectual disabilities cannot be assumed (e.g. cerebral palsy, autistic spectrum disorder (ASD)) where results not disaggregated for people with intellectual disabilities

- Study solely of infants (less than one year of age)

- Only includes information relating to prevalence of dysphagia (these studies were retained for a separate review [39])

Initially, titles and abstracts were used to exclude studies obviously not within the scope of the review $\left(1^{\text {st }}\right.$ author $)$. Those retained for further screening were those for which relevance could not be assessed without accessing full text, or those that were potentially within scope. These studies were screened by two authors ( $1^{\text {st }}$ and last author) and discussed until consensus was reached on whether they met the inclusion criteria. All relevant studies were included in the review regardless of methodological quality, with studies being categorised by research design in order to illustrate the overall number of studies identified in relation to established hierarchies of evidence [42].

\section{Data extraction and synthesis}

Data were extracted from the full text of included studies by the first author. Textual summaries were produced for each study in relation to: bibliographic details; the country 
within which the study took place; details of the focus of the study; sample size and characteristics; study design and data sources; measures employed; main results; and issues raised in the discussion. No exclusion criteria were applied with the aim of the textual summary being to produce a comprehensive summary of the paper. This information was then tabulated in an Excel database. An iterative approach was taken in which a list of themes was identified via reading and re-reading the study summaries in Excel and these themes were allocated to overarching themes [43]. The themes and overarching themes identified were entered into the Excel database for each study. These were then checked by the last author and discussed until consensus was reached.

Results were collated, summarised and reported via a tabulation of key data, descriptive numerical summary of included studies (e.g. number with particular research designs) and a descriptive narrative summary of the identified themes. It was generally not possible to compare results between studies directly due to variation in the methods used.

\section{Results}

The process of identifying studies for inclusion is summarised in Figure 1. Electronic database searches identified 799 references, with 561 remaining after removal of 238 duplicates. Following the first screening, 441 references were excluded and 120 remained for further screening. After examination of full text and the addition of studies cited within these, 35 studies met the criteria for inclusion. These are summarised in Table 1.

The following themes were identified: characteristics of dysphagia; health conditions associated with dysphagia (respiratory infections, choking/asphyxiation, nutritional status); mortality; health service use; practice and knowledge in supporting people with intellectual 
disabilities and dysphagia; intervention effectiveness; and quality of life. Information relating to these themes, and the geographical spread and design of the studies, is described below. Information relating to dysphagia prevalence was considered in a separate review.

Figure 1 Here

\section{Geographical spread}

All studies were undertaken in high income countries. In terms of geographical spread, the greatest number of studies were from the United Kingdom (UK), including 15 from England, and one each from the UK generally, and Scotland, and England and Wales combined. Ten studies were from the United States (US), two from Australia; and one each from France, Italy, Ireland, the Netherlands and Singapore.

\section{Table 1 Here}

\section{Study Design}

The design of each study is summarised in Table 1. Most studies were descriptive, based on review of medical or other records, interview or questionnaire based studies, observations of mealtimes, clinical assessments, or qualitative studies. There was one prospective 6-month observational cohort study on the association between oral microbial and respiratory status [44]. Only five intervention studies were identified. None of these were RCTs and only two considered outcomes for people with intellectual disabilities, one using a single-subject multiple treatment design [45], and one prospective controlled non-randomised (quasiexperimental) trial [46]. Other intervention studies related to the outcomes of training for caregivers: one used a between-subjects experimental design with three training conditions and pre, post and 3-10 month follow-up [18]; one used a pre- post- design with no comparison group [47]; and one used repeated measures with a control group [48]. Other 
studies including information related to interventions were limited to audits, retrospective review of records and patient monitoring.

\section{Characteristics of dysphagia}

Some information is available on the stages of swallow affected for those with dysphagia. Of 90 children with cerebral palsy and dysphagia, almost all had abnormalities of both the oral (98\%) and pharyngeal (99\%) phases of deglutition [49]. Of 40 adults with intellectual disabilities who had been in contact with Speech and Language Therapists (SLTs), dysphagia presented at the oral stage for $97.5 \%$, pharyngeal $65 \%$, oesophageal $17.5 \%$, and more than one stage $67.5 \%$ [50]. Detailed descriptions of problems at different stages of swallow are given for 99 people with dysphagia referred to SLTs in one area of England [23]. Stages affected were: oral 94.1\%; pharyngeal 51.5\%; oesophageal 25.7\%; and more than one stage $58.4 \%$.

There is also some information available regarding aspiration in those with dysphagia. Chadwick and Jolliffe (2009) found that of those referred to SLTs with confirmed dysphagia, aspiration was identified in 46/96 (47.9\%), with silent aspiration [aspiration without a cough or other overt response, 51] in 30/96 (31.3\%). In an earlier sample of adults in contact with SLTs, 26/40 (65\%) aspirated [50]. Of 19 children with Down syndrome referred to a swallowing disorders clinic, 10/19 (52.6\%) aspirated during videofluoroscopic modified barium swallow (VMBS), 6 on thin liquid, 2 on thickened liquid, and 2 on both, but none on puree or solids [52]. Of 10 who aspirated, cough data was available for 8 and all were silent aspirators, exhibiting no cough following the aspiration event. Severity of observed oral motor difficulties was not found to be predictive of aspiration, indicating that the clinically observable oral phase cannot be used to predict reliably whether aspiration is or is not 
occurring. Of children with cerebral palsy, 5/15 (33.3\%) aspirated [53]. Of 90 children with cerebral palsy and dysphagia, VMBS studies showed that 34 (37.8\%) aspirated, 17 prior to or during swallowing, 17 after swallowing, and aspiration was silent in 97\% of those who aspirated [49]. Of adults referred to a feeding disorders clinic, 20/67 (29.9\%) aspirated, 70\% of whom had a history of respiratory distress during meals or a history of chronic lung disease [54]. Of children with cerebral palsy and intellectual disabilities with feeding problems, radiological results found aspiration in 7/40 (17.5\%) [55]. For people with Down syndrome, hypotonicity and altered anatomy of the oral cavity may affect swallowing [31] and although no participants in this study were reported by caregivers to have any oral feeding difficulties, mealtime observation revealed coughing on food and/or drink (a sign of possible aspiration) in 13 participants (56.5\%) [31]. Finally, of 21 children with Down syndrome referred for feeding problems, many ate only pureed or low-textured food and refused to chew, despite having the ability to chew, which could be a learned aversion [56].

\section{Health Conditions Associated with Dysphagia}

\section{Respiratory Infections}

Respiratory infections are commonly reported in people with intellectual disabilities and dysphagia including: $13.5 \%$ of children with severe cerebral palsy and dysphagia having two or more lower respiratory tract infections (LRTIs) per year [57]; 27.6\% of children with Down syndrome and pharyngeal dysphagia having pulmonary conditions such as recurrent pneumonia and bronchitis [30]; $53.3 \%$ of children with cerebral palsy and dysphagia having a history of at least one episode of pneumonia and more frequent episodes of pneumonia than those without dysphagia (1-2 episodes $26.7 \%$ vs. $9.8 \% ; 3$ or more episodes $26.7 \%$ vs. $7.3 \%$ ) [53]; $94.7 \%$ of children with Down syndrome referred to a swallowing disorders clinic having a history of respiratory problems including $10(52.6 \%)$ with a history of pneumonia 
[52]; 39.4\% of adults having had more than one aspiration-related respiratory tract infection (RTI) in the previous year [23]; and one third of participants with any mealtime support needs (including but not limited to dysphagia) having had a respiratory infection in each year studied and $21.3 \%$ having had respiratory infections in both years [58].

Respiratory infections have been found to be associated with aspiration. In one study, those who aspirated were significantly more likely to have a history of recurrent chest infections, with almost two thirds of those identified as aspirating on videofluoroscopy $(64.5 \%, \mathrm{n}=20)$ having had more than one chest infection in the previous 12 months (compared to $27.8 \%$ of those who did not aspirate) [23]. Of 67 adults referred to the Feeding Disorders Clinic of a large residential facility, 20 aspirated and those who aspirated were more likely to have chronic lung disease (55\% vs. $4 \%$ ) including chronic infiltrates, recurrent pneumonia, pulmonary fibrosis, chronic obstructive pulmonary disease, bronchiectasis and asthma [54]. In those who aspirated, those dependent on others for oral feedings were at highest risk of chronic lung disease. In one study, of 10 children who aspirated, 5 were referred due to recurrent pneumonia [52].

One prospective study considered the association of respiratory infections with the presence of oral micro-organisms and oral status in 63 people with intellectual disabilities who received routine toothbrushing (97\% with dysphagia) [44]. Twelve people (19.0\%) had pneumonia during the 6 months period. Participants with microorganisms in their baseline samples were significantly more likely to develop any respiratory infection and those who had poor oral status were significantly more likely to develop pneumonia. 
Finally, in a study of children (not necessarily with intellectual disabilities) presenting for evaluation of feeding and swallowing dysfunction, factors associated with pneumonia included Down syndrome, although with only 6 children with Down syndrome in the study the $95 \%$ confidence interval for the odds ratio is wide (OR 22.10, 95\% CI 2.4, 202.2) [59].

\section{Choking/asphyxiation}

Choking has been found to be common in people with intellectual disabilities and dysphagia. In a study of adults identified as having dysphagia by speech therapy services, incident reports were regularly kept for 58 of the 80 participants, 41 of whom $(70.7 \%)$ had had a near fatal choking incident identified by a serious choking and/or coughing incident in the previous year [6]. For children with cerebral palsy those with dysphagia were more likely to choke with meals, with 2 or more episodes occurring in 3 months in 12/15 (80\%) of those with dysphagia but in none of the children without dysphagia [53]. In a study of adults with dysphagia where risks were reported based on clinical, videofluoroscopic and case history information, 89/99 (89.9\%) were classified as at high risk of asphyxia [23].

Variables identified via logistic regression as predictive of asphyxiation risk as rated by SLTs included maladaptive eating strategies (cramming and speed of eating), and the physiological factor of premature loss of the bolus into the pharynx [6]. All people with these three factors as problems (speed, cramming and premature loss of the bolus) were classified as being at high risk of asphyxiation, and 84.6\% $(\mathrm{n}=11)$ had had a near-fatal choking incident.

Based on a survey of 674 carers of adults with intellectual disabilities, Down syndrome diagnosis (OR 1.60 (95\% CI 1.08, 2.35)), needing help with liquids (OR 4.46 (95\% CI 1.74, 11.46)), inability to read (OR $1.40(95 \%$ CI 1.01, 1.95)) and being on tranquillizers (OR 1.89 
(95\% CI 1.21, 2.94)) were associated with an increase in the odds of choking in a multivariate predictive model [60]. 'Needing help with liquids' and 'inability to read' are factors associated with more severe intellectual disability. Based on in-depth interviews with a subsample of 18 who reported serious or unusual choking history, antisocial eating habits learnt in institutional settings (e.g. stealing and bolting food) presented an additional choking hazard for some individuals. However, it should be noted that this latter study is about choking generally, some of which may not be dysphagia related.

A thematic analysis of choking incident report narratives in England and Wales for intellectual disability or mental health settings, and for a local specialist intellectual disability residential setting, identified 6 subthemes relating to staff perceptions of factors influencing the risk of choking [61]: care pathway; time of day (40\% of local incidents were at the evening meal); food types; medication (including antipsychotic side effects); behaviours (e.g. cramming or rushing food); and familiarity of staff. There were $15(3 \%)$ incidents where choking was associated with either difficulty swallowing medication or with delayed effects such as the longer lasting side-effects of antipsychotic medication, although no locally reported incidents mentioned medication side-effects [61]. Analysis of conversations with staff involved in recent choking incidents in the specialist setting emphasised service user behaviour and social and environmental aspects of mealtimes, such as unwelcome close proximity to others, increased agitation due to noise and proximity, and a perceived need for increased staffing and staff familiar with residents at evening meals [62].

\section{Nutritional status}

In a study of 318 patients at a large hospital for people with intellectual disabilities and 99 living in the community, over $60 \%$ of children and adults with intellectual and neurological 
handicaps (usually cerebral palsy) were underweight (body mass index (BMI) 20 or less) as a result of swallowing difficulties [10]. In a study of adults with dysphagia where risks were reported based on clinical, videofluoroscopic and case history information, 67/99 (67.7\%) were classified as at high risk of dehydration, and 57/99 (57.6\%) at high risk of poor nutritional status [23]. Finally, a study of adults with mealtime support needs based on questions about GP and hospital visits found that there were nutritional concerns (undernutrition or dehydration) for 20/127 (15.7\%) in year one and 13/124 (10.5\%) in year two [58].

\section{Mortality}

Of 142 adults with intellectual disabilities and eating, drinking and swallowing (EDS) related problems (including but not restricted to dysphagia), 8 (5.6\%) died between baseline and 12 month follow-up giving a SMR of 267 (exact 95\% CI 115, 526), with nearly 3 times as many dying as would be expected in the general population of people with intellectual disabilities [58]. Respiratory infections were the immediate cause of death in all 8 cases: 3 from pneumonia; 2 bronchopneumonia; 2 aspiration pneumonia; and 1 from an unspecified chest infection.

\section{Health service use}

One study looked at health service use for adults with intellectual disabilities with any EDS problem over two years [58]. Each year, the majority (85-95\%) visited their GP at least once, while around $20 \%$ attended hospital for any emergency reason in year one. Around one in five GP and emergency hospital visits were for EDS problems. For those who saw the GP for an EDS-related problem, the primary cause was respiratory infections in both year 1 $(47 / 58(81.0 \%))$ and year $2(30 / 38(78.9 \%))$. Respiratory infections were also the most 
common single reason for EDS-related emergency hospitalizations in year $2(9 / 21(43 \%))$ of which 4 were specifically for aspiration pneumonia.

\section{Practice and knowledge in supporting people with intellectual disabilities and dysphagia}

There is scant research available on current practice in relation to supporting people with intellectual disabilities and dysphagia. At the time an audit of adults with profound intellectual disabilities was undertaken in one area of England, there was no funding for a dysphagia service for adults with intellectual disabilities, and this was acknowledged as a service deficiency [63]. Audit results provided evidence for the need for such a service, which was subsequently provided. A study looking at choking incident reports relating to intellectual disability or mental health settings found that some reports indicated unmet need where SLT input was not available [61]. One study looked at the availability of speechlanguage services for adults with intellectual disabilities in South-Eastern Ontario [64]. Swallowing assessments (videofluoroscopic and bedside) were available for all adults with an intellectual disability at designated local hospitals and through Community Care Access Centres, respectively. However, direct treatment, staff training, and follow up services were limited. Once a client had met their therapeutic goals and the services of the speech and language pathologist (SL-P) were removed, implementation of the daily functional program was often discontinued. Finally, a study on current practice when recommending tastes for people with intellectual disabilities who are non-orally fed found that 43/55 (78.2\%) SLTs or dieticians working primarily with people with intellectual disabilities had recommended tastes to those who are enterally fed [65].

A recent case-note audit of acute general and mental health service inpatients found that overall, less than $20 \%$ of 176 people with intellectual disabilities received a swallowing 
assessment, with the figure being 31/109 (28.4\%) for general services, and 3/67 (4.5\%) for mental health services [66].

More research is available on the role of staff and carers in supporting people with intellectual disabilities and dysphagia. Firstly, studies have looked at caregivers in relation to knowledge of and adherence to SLT dysphagia management guidelines $[16,50,67,68]$. In a study of carer knowledge of individuals' dysphagia management strategies carers recounted a significantly greater proportion of strategies relating to dietary modification and equipment use compared with positioning recommendations and demonstrated least knowledge of support, prompting and socializing recommendations [67]. Adherence to guidelines has been found to be high overall (76.6\%) but differing according to the type of guideline, with higher adherence to guidelines regarding food/drink consistency $($ mean $=89.7 \%, \mathrm{SD}=16.9$ ), positioning $($ mean $=89.3 \%, \mathrm{SD}=16.3)$, and utensil use $($ mean $=79.2 \%, \mathrm{SD}=23.1)$ and much lower adherence for guidelines pertaining to support, prompting, and socializing (mean $=64.4 \%, \mathrm{SD}=26.4)[50]$. In $50 \%$ of cases, eating and drinking occurred too fast compared to guideline recommendations and in some cases the speed increased as the meal progressed. Generally, only one or at most two swallows occurred prior to presentation of the ensuing bolus. A further study on adherence to recommendations in day centres found that overall compliance was $82 \%$, ranging from $64 \%$ compliance with appropriate utensils to $100 \%$ with direct support recommendations, and 79\% with food preparation compliance [68].

A study on caregiver reported barriers to compliance with eating and drinking recommendations identified numerous barriers including difficulties in modifying food and drinks to safe consistencies, achieving the agreed positioning during mealtimes, and in using support and prompting strategies [16]. Other barriers included time pressures, staff turnover, 
inconsistency between settings (e.g. recommended cup not being used at home), and physical or behavioural difficulties of the person with intellectual disabilities. In a day centre, noted difficulties included utensils not always being available, difficulties obtaining suitable food from the kitchen, difficulty supervising those who did not need one to one support as no one is identified to do this specifically, with staff working with those with higher support needs [68].

Finally, in a study of clinical and radiographic features of dysphagia in adults, mostly with profound intellectual disabilities, modified barium fluoroscopic swallow studies could be effectively completed even for adults with the most severe handicaps with proper positioning equipment for non-ambulatory individuals and patient, interested radiologists being essential [54].

There is a small amount of information indicating that aspects of caregiver support can have an impact for people with intellectual disabilities and dysphagia. In a survey of speechlanguage pathology services in South Eastern Ontario, it became clear that staffing changes and turnover rates had a negative impact on the consistent implementation and use of communication and feeding/swallowing strategies [64]. In a study on the efficacy of a feeding skill and mealtime behaviour intervention, a decrease of $7 \%$ in feeding skills was recorded across all participants when school staff delivered the intervention, suggesting a need for advanced training and support for school staff members working with children and youth with feeding problems [45]. A study of choking incident reports from intellectual disability or mental health care settings suggested a potential for heightened risk associated with unfamiliar staff (e.g. agency workers being unaware of need to use thickener), and some reports indicated that inappropriate food textures may have been given [61]. 
Indeed, some studies suggest that some caregivers may lack knowledge regarding dysphagia. In a study on dysphagia training for support workers, the control group had a combination of high confidence scores and low knowledge scores, potentially putting clients at risk of choking, chest infections and aspiration pneumonia due to not recognising or underestimating problems and therefore mismanaging them [48]. In one study, carers demonstrated knowledge of the risks of aspiration and asphyxiation, but one-third demonstrated a lack of awareness of all of the relevant risks of non-compliance, in particular tending to overlook the risk of poor nutritional status, injury during mealtimes and dehydration [67]. In a study on dysphagia training in a specialist education setting, before training some staff were: unsure about how to mix thickeners and modify textures correctly; considered giving occasional snack foods such as cheesy corn puffs would not cause risk; perceived coughing to be a protective mechanism that would prevent aspiration; and lacked understanding of the relationship of positioning to the safety of eating and drinking [47]. In a study of day centre staff, 21/27 (77.8\%) were aware that their client had eating and drinking recommendations and 18/27 (66.7\%) had had any training in eating and drinking [68]. Finally, some family caregivers appear to be more resistant to using dysphagia guidelines and, on occasion, gave authors the impression that they did not like being "told" how to feed their own family members [50]. Some parents gave indirect evidence that dysphagia guidelines had not altered their method of giving meals and drinks [16].

For caregivers, dysphagia can be a source of anxiety. In a study of the concerns of staff carers of people with Down syndrome and advanced dementia, one of three themes identified was the fear of feeding someone with swallowing difficulties and the anxiety it generated 
[69]. Being involved in a choking incident can be emotionally stressful for staff, with incidents described using words such as "scariest" and "most frightening" [62].

\section{Intervention effectiveness}

A small number of studies consider interventions relevant to people with intellectual disabilities and dysphagia. Four studies (none of which were experimental intervention studies) presented information relating to enteral feeding. In a study on pneumonia before and after enteral tube feeding, there was a significant $45 \%$ decrease in pneumonia in the year following tube insertion [70]. In a Scottish study, 40 patients with PEG tubes were monitored for a median of 102 weeks (range 16-288 weeks) and median weight rose from 29 to $38 \mathrm{~kg}(+31 \%)$, and median percentage body fat from $11 \%$ to $20 \%(+82 \%)[10]$. An English audit of PEG placements found that the procedure was generally safe and resulted in modest weight gain [71]. For 36 people where information was available, after a median follow-up of 21.5 months, mean overall weight gain was $2.3 \mathrm{~kg}$ but 7 (17\%) patients lost weight. Overall, 31 (74\%) experienced at least one complication and 30 day mortality was zero. An audit on health and social outcomes of PEG feeding for 40 people with intellectual and physical disabilities in Australia found weight increases in 17 out of 26 who had been underweight, and 11 people were able to return to community activities after PEG feeding as they were less ill but two thirds were unable to return to pre-PEG community activities [72]. The authors of this audit suggest that people with intellectual and physical disabilities may live for many years with PEG feeding but that quality of life gains were limited and all experienced complications.

Only three studies considered other interventions in relation to outcomes for people with intellectual disabilities. A prospective longitudinal controlled and nonrandomised (quasi- 
experimental) trial using an occlusal orthotic appliance for the mandibular arch in adults with Down syndrome to increase inter-arch contacts found that increasing the number of posterior functional units (PFUs) led to a decrease in bolus particle size, to fewer masticatory cycles needed to produce a bolus ready for swallowing and to a decrease in the occurrence of food refusal, while mean chewing frequency did not vary [46]. A fluid programme aimed at providing 2.5 litres of fluid daily for patients with nutrition/dysphagia disorders led to an immediate fall in acute hospital admissions with hypematraemic dehydration [10]. Finally, an intervention in an educational setting found that a combined dysphagia treatment and behaviour management program was more effective than either program used alone for target feeding skills in children with intellectual disabilities [45].

Three studies have found positive results following caregiver training related to dysphagia. A study based on 6 dysphagia training sessions over a 6 week period for staff in an education setting for children with profound and multiple intellectual disabilities found improvements in knowledge post-training [47]. One-day dysphagia training for support workers of adults with intellectual disabilities led to gains in knowledge and confidence (e.g. 13 of 25 participants' scores went from 1 'not confident' to 4 'very confident' in achieving recommended drink consistency) and this gain was maintained a month after having attended the training [48]. In a study on training support staff who had no prior experience of modifying fluid consistencies, the group trained using Thickness Indicator Model (TIM) tubes alongside typical training and written guidance were more accurate at modifying fluids at 3-10-month follow-up than those receiving written guidance alone or typical training with written guidance, being $41.8 \%$ more accurate than they were prior to training [18]. Whilst further research in clinical settings is required to confirm the effectiveness of training and TIM tubes, they may also enable caregivers to more accurately cascade the information about 
individual management strategies for people requiring modification of liquids which may also help caregivers to more consistently modify fluids accurately over time. This is particularly important in situations where people are reliant on multiple caregivers and where frequent staff changes occur. However, at the present time these tubes do not appear to be available for purchase. Moreover, these training studies did not assess compliance with recommendations [cf. 16, 68] or the application of practical skills when supporting people with intellectual disabilities and dysphagia.

\section{Quality of life}

The issue of the quality of life of people with intellectual disabilities and dysphagia, or how people experience aspects of dysphagia such as choking episodes, has received little attention. One study looking at current practice when recommending tastes for people with intellectual disabilities who are non-orally fed found that clinical decision-making with regards to offering tastes centred on balancing the wellbeing and wishes of the person with intellectual disabilities and their carers, with the risks of an oral taste programme [65]. However, there is no empirical research to confirm the clinical experience derived belief that introducing tastes is potentially beneficial to emotional well-being and inclusion in the sharing of life through meals and drinks [65].

In an observational study of adherence to eating and drinking guidelines, anecdotal evidence suggested that some of the more cognitively able people often objected to being watched or prompted or to having the consistency of their food altered [50]. In a subsequent study on barriers to caregiver compliance with eating and drinking recommendations, a common issue was the 'conflict between foods/consistencies safe for the person to eat and drink and the diet 
that the person actually wants' [16]. Two caregivers reported that their clients did not like the taste of thickened drinks, and five mentioned that dysphagic people were acutely aware of the difference between their modified food and the food available to other people. One person described, with distaste, his food as 'like baby food' because of its uniform smooth consistency. There was a need to balance quality of life and risk as evidenced in the following quote:

"Denying Paula things she wants is difficult. She told her staff when she was out once that she could have a burger ... she ate it ... ended up in hospital ... (and) nearly choked" [p157, $16]$.

\section{Discussion}

This review identified a relatively large number of studies relating to dysphagia and people with intellectual disabilities covering a broad range of issues. This discussion synthesises the evidence (including gaps) and the implications of the body of evidence are outlined.

For people with intellectual disabilities and dysphagia, difficulties are often evident at multiple stages of the swallowing process. One alarming finding is that a high proportion of those people with intellectual disabilities who aspirate do so silently $[23,49,52]$. Even if caregivers are aware of the indicators of aspiration, silent aspiration can go unnoticed and may have chronic health implications [23]. It has been suggested that those with signs of pharyngeal phase swallowing difficulties should be referred for imaging diagnostic techniques [57]. However, in practice access to such diagnostic techniques may be limited, with SLTs having to rely on clinical assessment. 
Although a relatively high proportion of people with intellectual disabilities who aspirate develop chest infections, this is not inevitable [23]. One factor found to be associated with pneumonia in people with intellectual disabilities and dysphagia is oral microbial status, and it has been suggested that the oral cavity of people with intellectual disabilities serves as a reservoir for bacteria that may be aspirated into the lungs, especially in persons with swallowing disorders [44]. They suggest that meticulous, comprehensive oral hygiene may be needed to reduce oropharygeal microbial load and that caregivers who provide oral hygiene for persons with intellectual disabilities should be aware of the person's swallow status. However, providing oral care to people with intellectual disabilities and dysphagia can present challenges [73].

It has been suggested that mealtime support provided by caregivers to people with intellectual disabilities can have an influence on health and ultimate risk of death [35]. Noncompliance with dysphagia management advice in people without intellectual disabilities has been associated with adverse outcomes, including chest infection, aspiration pneumonia, and death [74]. A small amount of information from studies suggests that aspects of caregiver support can have an impact for people with intellectual disabilities and dysphagia [45, 61, 64]. This, in conjunction with results suggesting that some caregivers lack knowledge regarding dysphagia [47, 48, 67], and the apparent reluctance of some family caregivers to follow management guidelines $[16,50]$, highlights the importance of educating caregivers regarding dysphagia and the importance of adhering to guidelines. Further, barriers to adherence to guidelines include, for example, difficulties obtaining suitable food from the kitchen [68] indicating that education should be extended beyond those providing direct support. However, only three intervention studies related to caregivers were identified, all of which 
were small scale evaluations of training $[18,47,48]$. Awareness should also be raised in generic services that may be accessed by people with intellectual disabilities. Despite dysphagia being identified as a key risk area for patients with intellectual disabilities [26], less than $20 \%$ of inpatients with intellectual disabilities were found to have received a swallowing assessment [66].

It is clear that dysphagia is associated with serious health risks for people with intellectual disabilities. Despite this, only two intervention studies were identified that considered outcomes for people with intellectual disabilities $[45,46]$. Beyond these, information on the outcomes of interventions for people with intellectual disabilities is limited to audits, retrospective review and patient monitoring in relation to PEG feeding. Research employing robust research designs is needed to investigate the efficacy and effectiveness of different approaches to dysphagia management in people with intellectual disabilities

Dysphagia can also have a negative impact on the quality of life of people with intellectual disabilities $[16,50]$. Education, such as accessible explanations of why meal and drink modifications are required, might help people with intellectual disabilities understand why they are being treated differently [16]. More information is needed on the impact that dysphagia and its management has on the quality of life of people with intellectual disabilities and the tension between choice making and dysphagia management recommendations.

\section{Gaps in the evidence base}

There are notable gaps in the evidence base identified in this review. Currently there is no strong evidence for dietary modification as a successful management strategy for people with 
intellectual disabilities, despite its common use [73]. More evidence surrounding the impacts of consistency modification on psychological wellbeing and stigma, and regarding the correspondence between different consistencies of food and drink and particular problems in deglutition in people with intellectual disabilities is needed. More evidence is also needed regarding postural manoeuvres and physical positioning during mealtimes for people with intellectual disabilities and dysphagia. In addition, beyond the mealtime setting, long-term postural care may prevent changes in body shape that can cause problems with swallowing $[75,76]$ but research on this is lacking. Further, whilst there is a link between the side-effects of medications such as neuroleptics and dysphagia [28], this review found no research on this issue for people with intellectual disabilities. Such research is warranted in view of the fact that people with intellectual disabilities are more likely than others to be prescribed such medications [e.g. antipsychotics, 29]. Finally, no studies were identified from low and middle income (LAMI) countries, and no studies have included the 'hidden majority' of adults with intellectual disability who are not known to intellectual disability services [77].

\section{Limitations}

There are a number of limitations to this review. One weakness is the potential loss of information from two main sources. Firstly, the review has not considered how research regarding dysphagia in other populations may be applicable to people with intellectual disabilities, most notably cerebral palsy. Studies relating to cerebral palsy have only been included where at least half the sample are clearly noted to have an intellectual disability and findings from, for example, a study on the reliability of an asynchronous telehealth model for evaluating dysphagia in children with cerebral palsy [78], a prospective longitudinal population-based study on children with cerebral palsy [79], and in depth interviews with 
adults with cerebral palsy [37] are not included. Secondly, the review does not consider research relating to specific syndromes associated with intellectual disabilities such as Rett syndrome although it is evident that such research exists [e.g. 34, 80]. These may lead to unique issues, for example in Rett syndrome it has been suggested that involuntary tongue retroflexions affect swallowing and as these have not been reported in other dysphagic paediatric populations they should be considered 'provisionally-unique' to Rett syndrome [33]. These sources of information remain to be reviewed. In addition, whilst studies were identified from a range of countries, the review is restricted to English language publications. Finally, all data was extracted by one reviewer and extraction of data by two reviewers independently would have reduced the possibility of errors.

\section{Conclusion}

Dysphagia is common in people with intellectual disabilities and may be under-recognised. Improved recognition and management of dysphagia may reduce the occurrence of associated health conditions and reduce hospital admissions and premature death. Many unstudied and unanswered questions pertaining to dysphagia in people with intellectual disabilities remain. Chadwick and Jolliffe (2009) [23] highlight some of the areas where more research is needed, including: the need to discern more accurately the prevalence of dysphagia in people with intellectual and developmental disabilities, especially those in middle and low income countries; prospective case-control investigations charting the links between dysphagia, associated risks and mortality; investigation of dysphagia across the life course in people with intellectual disabilities; and further exploration of the effectiveness of different management strategies in preventing risk and improving quality of life. There is an urgent need for research on improving the management of dysphagia in people with intellectual disabilities 
and a need for education for staff, family carers and people with intellectual disabilities. A recent report provides ideas, information and examples of good practice in relation to reasonable adjustments that can be made to improve dysphagia care for people with intellectual disabilities [81]. 


\section{Appendix One: Example of Database Specific Search (Medline)}

( (MH "Deglutition Disorders+") OR TI dysphagi* OR AB dysphagi* OR TI swallow* OR AB swallow* OR TI deglutition OR AB deglutition )

AND

( (TI ( learning N1 (disab* or difficult* or handicap*) ) OR TI ( mental* N1 (retard* or disab* or deficien* or handicap*) ) OR TI ( intellectual* N1 (disab* or impair* or handicap*) ) OR TI development* N1 disab* OR TI ( multipl* N1 (handicap* or disab*) ) OR TI "Down* syndrome" OR (MH "Developmental Disabilities") OR (MH "Intellectual Disability+") OR (MH "mentally disabled persons")) OR (AB ( learning N1 (disab* or difficult* or handicap*) ) OR AB ( mental* N1 (retard* or disab* or deficien* or handicap*)) OR AB ( intellectual* N1 (disab* or impair* or handicap*) ) OR AB development* N1 disab* OR AB ( multipl* N1 (handicap* or disab*) ) OR AB "Down* syndrome"))

Limits: English language, human, published from 1990. 


\section{References}

1. Hollins S, Attard MT, von Fraunhofer N, McGuigan S, Sedgwick P. Mortality in people with learning disability: risks, causes, and death certification findings in London. Developmental Medicine \& Child Neurology. 1998;40:50-6. Epub 1998/02/12.

2. Marik PE. Aspiration pneumonitis and pneumonia: a clinical review. New England Journal of Medicine. 2001;344:665-72.

3. Martino R, Foley N, Bhogal S, Diamant N, Speechley M, Teasell R. Dysphagia After Stroke: Incidence, Diagnosis, and Pulmonary Complications. Stroke. 2005;36:2756-63.

4. Heslop P, Blair PS, Fleming P, Hoghton M, Marriott A, Russ L. The Confidential Inquiry into premature deaths of people with intellectual disabilities in the UK: a populationbased study. Lancet. 2014;383:889-95.

5. Finestone HM, Fisher J, Greene-Finestone LS, Teasall RW, Craig ID. Sudden death in the dysphagic stroke patient-a case of airway obstruction caused by a food bolus. American Journal of Physical Medicine and Rehabilitation. 1998;77:550-52.

6. Samuels R, Chadwick DD. Predictors of asphyxiation risk in adults with intellectual disabilities and dysphagia. Journal of Intellectual Disability Research. 2006;50:362-70.

7. National Patient Safety Agency. Problems swallowing? Ensuring safer practice for adults with learning disabilities who have dysphagia: resources for healthcare staff. Retrieved from http://www.nrls.npsa.nhs.uk/EasySiteWeb/getresource.axd?AssetID=60131\&type=full\&servi cetype=Attachment (accessed 14 May 2015)2007.

8. Ames J, Karnell L, Gupta A, Coleman T, Karnell M, Van Daele D, Funk G. Outcomes after the use of gastrostomy tubes in patients whose head and neck cancer was managed with radiation therapy. Head \& Neck. 2011;33:638-44. 
9. Karvonen-Gutierrez CA, Robis DL, Fowler KE, Terrell JE, Gruber SB, Duffy SA. Quality of life scores predict survival among patients with head and neck cancer. Journal of Clinical Oncology. 2008;26:2754-60.

10. Kennedy M, McCombie L, Dawes P, McConnell KN, Dunnigan MG. Nutritional support for patients with intellectual disability and nutrition/dysphagia disorders in community care. Journal of Intellectual Disability Research. 1997;41:430-6.

11. MacDonald NJ, McConnell KN, Stephen MR, Dunnigan MG. Hypernatraemic dehydration in patients in a large hospital for the mentally handicapped. British Medical Journal. 1989;299 (6713):1426-9.

12. Mick R, Vokes EE, Weichselbaum RR, Panje WR. Prognostic factors in advanced head and neck cancer patients undergoing multimodality therapy. 1991;105:62-73.

13. Cichero J. Conditions commonly associated with dysphagia. In: Cichero J, Murdoch B, editors. Dysphagia: Foundations, Theory and Practice. Chichester: Wiley \& Sons; 2006. 14. Eustace G, Gui XY, Iacucci M. Recent advances in the recognition and management of eosinophilic esophagitis. Canadian Journal of Gastroenterology and Hepatology. $2015 ; 29: 237-40$.

15. Robbins J, Gensler G, Hind J, Logemann JA, Lindblad AS, Brandt D, Baum H, Lilienfeld D, Kosekm S, Lundy D, K. D, Kazandjian M, Gramigna GD, McGarvey-Toler S, Gardner PJM. Comparison of two interventions for liquid aspiration on pneumonia incidence. Annals of Internal Medicine. 2008;148:509-18.

16. Chadwick DD, Jolliffe J, Goldbart J, Burton MH. Barriers to Caregiver Compliance with Eating and Drinking Recommendations for Adults with Intellectual Disabilities and Dysphagia. Journal of Applied Research in Intellectual Disabilities. 2006;19:153-62.

17. Miller N, Noble E, Jones D, Burn D. Hard to swallow: dysphagia in Parkinson's disease. Age and Ageing. 2006;35:614-8. 
18. Chadwick DD, Stubbs J, Fovargue S, Anderson D, Stacey G, Tye S. Training support staff to modify fluids to appropriate safe consistencies for adults with intellectual disabilities and dysphagia: an efficacy study. Journal of Intellectual Disability Research. 2014;58:84-98. 19. Colodny N. Dysphagic independent feeders' justifications for non-compliance with recommendations by a speech-language pathologist. American Journal of Speech \& Language Pathology. 2005; 14:61-70.

20. Ekberg O, Hamdy S, Woisard V, Wuttge-Hannig A, Ortega P. Social and psychological burden of dysphagia: Its impact on diagnosis and treatment. Dysphagia. 2002;17:139-46.

21. Roe JWG, Leslie P, Drinnan MJ. Oropharyngeal dysphagia: the experience of patients with non-head and neck cancers receiving specialist palliative care. Palliative Medicine. 2007;21:567-74.

22. Parkes J, Hill N, Platt MJ, Donnelly C. Oromotor dysfunction and communication impairments in children with cerebral palsy: a register study. Developmental Medicine \& Child Neurology. 2010;52:1113-9.

23. Chadwick DD, Jolliffe J. A descriptive investigation of dysphagia in adults with intellectual disabilities. Journal of Intellectual Disability Research. 2009;53:29-43.

24. Patja K, Mölsä P, Iivanainen M. Cause-specific mortality of people with intellectual disability in a population-based, 35 year follow-up study. Journal of Intellectual Disability Research. 2001;45:30-40.

25. Glover G, Ayub M. How People with Learning Disabilities Die. Improving Health \& Lives: Learning Disabilities Observatory, http://www.improvinghealthandlives.org.uk/gsf.php5?f=8586\&fv=9033 (accessed 25 November 2014)2010. 
26. National Patient Safety Agency. Understanding the patient safety issues for people with learning disabilities. Retrieved from http://www.npsa.nhs.uk/EasySiteWeb/GatewayLink.aspx?alId=839 (accessed 14 May 2015)2004.

27. Hemsley B, Balandin S, Sheppard JJ, Georgiou A, Hill S. A call for dysphagia-related safety incident research in people with developmental disabilities. Journal of Intellectual and Developmental Disability. 2015;40:99-103.

28. Dziewas R, Warnecke T, Schnabel M, Ritter M, Nabavi D, Schilling M, Ringelstein E, Reker T. Neuroleptic-Induced Dysphagia: Case Report and Literature Review. Dysphagia. 2007;22:63-7.

29. Glover G, Williams R, Branford D, Avery R, Chauhan U, Hoghton M, Bernard S. Prescribing of psychotropic drugs to people with learning disabilities and/or autism by general practitioners in England. London, available online at http://www.improvinghealthandlives.org.uk/gsf.php5?f=313881\&fv=21599 (accessed 24 September 2015): Public Health England 2015.

30. O'Neill AC, Richter GT. Pharyngeal Dysphagia in children with down syndrome. Otolaryngology-Head \& Neck Surgery. 2013;149:146-50.

31. Smith $\mathrm{CH}$, Teo Y, Simpson S. An observational study of adults with down syndrome eating independently. Dysphagia. 2014;29:52-60.

32. Shashi V, Fryburg JS. Vascular ring leading to tracheoesophageal compression in a patient with Rubinstein-Taybi syndrome. Clinical Genetics. 1995;48:324-7.

33. Abraham SS, Taragin B, Djukic A. Co-occurrence of Dystonic and Dyskinetic Tongue Movements with Oral Apraxia in Post-regression Dysphagia in Classical Rett Syndrome Years of Life 1 Through 5. Dysphagia. 2015;30:128-38. 
34. Motil KJ, Schultz RJ, Browning K, Trautwein L, Glaze DG. Oropharyngeal dysfunction and gastroesophageal dysmotility are present in girls and women with Rett syndrome. Journal Of Pediatric Gastroenterology And Nutrition. 1999;29:31-7.

35. Ball SL, Panter SG, Redley M, Proctor CA, Byrne K, Clare ICH, Holland AJ. The extent and nature of need for mealtime support among adults with intellectual disabilities. Journal of Intellectual Disability Research. 2012;56:382-401.

36. Sheppard J. Developmental disability and swallowing disorders in adults. In: Cichero J, Murdoch B, editors. Dysphagia: Foundations, Theory and Practice. Chichester: Wiley \& Sons; 2006.

37. Balandin S, Hemsley B, Hanley L, Sheppard JJ. Understanding mealtime changes for adults with cerebral palsy and the implications for support services. Journal of Intellectual \& Developmental Disability. 2009;34:197-206.

38. Roden DF, Altman KW. Causes of dysphagia among different age groups: a systematic review of the literature. Otolaryngologic Clinics Of North America. 2013;46:96587.

39. Robertson J, Chadwick D, Baines S, Emerson E, Hatton C. Prevalence of dysphagia in people with intellectual disability: a systematic review. Intellectual \& Developmental Disabilities. in press.

40. Collins JA, Fauser BCJM. Balancing the strengths of systematic and narrative reviews. Human Reproduction Update. 2005;11:103-4.

41. Sherman SL, Allen EG, Bean LH, Freeman SB. Epidemiology of Down syndrome. Mental Retardation and Developmental Disabilities Research Reviews. 2007;13:221-7.

42. Guyatt GH, Oxman AD, Kunz R, Vist GE, Falck-Ytter Y, Schünemann HJ. What is "quality of evidence" and why is it important to clinicians? BMJ. 2008;336:995-8. 
43. Braun V, Clarke V. Using thematic analysis in psychology. Qualitative Research in Psychology. 2006;3:77-101.

44. Binkley CJ, Haugh GS, Kitchens DH, Wallace DL, Sessler DI. Oral microbial and respiratory status of persons with mental retardation/intellectual and developmental disability: an observational cohort study. Oral Surgery, Oral Medicine, Oral Pathology, Oral Radiology \& Endodontology. 2009;108:722-31.

45. Bailey RL, Angell ME. Improving Feeding Skills and Mealtime Behaviors in Children and Youth with Disabilities. Education and Training in Developmental Disabilities. 2005;40:80-96.

46. Hennequin M, Mazille M-N, Cousson P-Y, Nicolas E. Increasing the number of interarch contacts improves mastication in adults with Down syndrome: A prospective controlled trial. Physiology \& Behavior. 2015;145:14-21.

47. Harding C, Halai V. Providing dysphagia training for carers of children who have profound and multiple learning disabilities. British Journal of Developmental Disabilities. 2009;55:33-47.

48. Tredinnick G, Cocks N. Effectiveness of dysphagia training for adult learning disabilities support workers. British Journal of Learning Disabilities. 2013;42:125-32.

49. Rogers B, Arvedson J, Buck G, Smart P, Msall M. Characteristics of dysphagia in children with cerebral palsy. Dysphagia. 1994;9:69-73.

50. Chadwick DD, Jolliffe J, Goldbart J. Adherence to eating and drinking guidelines for adults with intellectual disabilities and dysphagia. American Journal on Mental Retardation. 2003;108:202-11.

51. Weir KA, McMahon S, Taylor S, Chang AB. Oropharyngeal aspiration and silent aspiration in children. Chest. 2011;140:589-97. 
52. Frazier JB, Friedman B. Swallow function in children with Down syndrome: a retrospective study. Developmental Medicine \& Child Neurology. 1996;38:695-703.

53. Waterman ET, Koltai PJ, Downey JC, Cacace AT. Swallowing disorders in a population of children with cerebral palsy. International Journal Of Pediatric Otorhinolaryngology. 1992;24:63-71.

54. Rogers B, Stratton P, Msall M, Andres M, Champlain MK, Koerner P, Piazza J. Long-term mobidity and management strategies of tracheal aspiration in adults with severe developmental disabilities. American Journal on Mental Retardation. 1994;98:490-8.

55. Santoro A, Dasso Lang MB, Moretti E, Sellari-Franceschini S, Orazini L, Cipriani P, Cioni G, Battini R. A proposed multidisciplinary approach for identifying feeding abnormalities in children with cerebral palsy. Journal of Child Neurology. 2012;27:708-12. 56. Field D, Garland M, Williams K. Correlates of specific childhood feeding problems. Journal Of Paediatrics And Child Health. 2003;39:299-304.

57. Calis EAC, Veugelers R, Sheppard JJ, Tibboel D, Evenhuis HM, Penning C.

Dysphagia in children with severe generalized cerebral palsy and intellectual disability. Developmental Medicine \& Child Neurology. 2008;50:625-30.

58. Perez CM, Ball SL, Wagner AP, Clare ICH, Holland AJ, Redley M. The incidence of healthcare use, ill health and mortality in adults with intellectual disabilities and mealtime support needs. Journal of Intellectual Disability Research. 2015;59:638-52.

59. Weir K, McMahon S, Barry L, Ware R, Masters IB, Chang AB. Oropharyngeal aspiration and pneumonia in children. Pediatric Pulmonology. 2007;42:1024-31.

60. Thacker A, Abdelnoor A, Anderson C, White S, Hollins S. Indicators of choking risk in adults with learning disabilities: a questionnaire survey and interview study. Disability \& Rehabilitation. 2008;30:1131-8. 
61. Guthrie S, Lecko C, Roddam H. Care staff perceptions of choking incidents: What details are reported? Journal of Applied Research in Intellectual Disabilities. 2015;28:121-32.

62. Guthrie S, Stansfield J. Teatime Threats. Choking Incidents at the Evening Meal. Journal of Applied Research in Intellectual Disabilities. 2015;Online Early doi: 10.1111/jar.12218.

63. Gittins D, Rose N. An audit of adults with profound and multiple learning disabilities within a West Midlands Community Health Trust--Implications for service development. British Journal of Learning Disabilities. 2008;36:38-47.

64. Freeman C. Availability and delivery of speech-language pathology services for adults with intellectual disabilities in South-Eastern Ontario. Journal on Developmental Disabilities. 2003;10:81-91.

65. Chadwick DD. Balancing safety and enjoyment. Current practice when recommending tastes for people with intellectual disabilities who are non-orally fed. Appetite. 2014;81:152-61.

66. Sheehan R, Gandesha A, Hassiotis A, Gallagher P, Burnell M, Jones G, Kerr M, Hall I, Chaplin R, Crawford MJ. An audit of the quality of inpatient care for adults with learning disability in the UK. BMJ Open. 2016;6 doi: 10.1136/bmjopen-2015-010480.

67. Chadwick DD, Jolliffe J, Goldbart J. Carer knowledge of dysphagia management strategies. International Journal of Language \& Communication Disorders. 2002;37:345-57. 68. Crawford H, Leslie P, Drinnan M. Compliance with dysphagia recommendations by carers of adults with intellectual impairment. Dysphagia. 2007;22:326-34.

69. McCarron M, McCallion P, Fahey-McCarthy E, Connaire K, Dunn-Lane J. Supporting persons with Down syndrome and advanced dementia: challenges and care concerns. Dementia. 2010;9:285-98. 
70. Gray DS, Kimmel D. Enteral tube feeding and pneumonia. American Journal Of Mental Retardation: AJMR. 2006;111:113-20.

71. Ayres L, Black C, Scheepers M, Shaw I. An audit to evaluate the safety and efficacy of percutaneous endoscopic gastrostomy placement in patients with learning disabilities. British Journal of Learning Disabilities. 2015;43:201-7.

72. Lee L, MacPherson M. Long-term percutaneous endoscopic gastrostomy feeding in young adults with multiple disabilities. Internal Medicine Journal. 2010;40:411-8.

73. Chadwick D. Dysphagia management for people with intellectual disabilities: Practitioner identified processes, barriers and solutions. Journal of Policy \& Practice in Intellectual Disabilities. in press.

74. Low J, Wyles C, Wilkinson T, Sainsbury R. The Effect of Compliance on Clinical Outcomes for Patients with Dysphagia on Videofluoroscopy. An International Multidisciplinary Journal Devoted to Swallowing and Its Disorders. 2001;16:123-7. 75. Cobb J, Giraud-Saunders A. Commentary: Biomechanics and prevention of body shape distortion. Tizard Learning Disability Review. 2010;15:30-2.

76. Hill S, Goldsmith J. Biomechanics and prevention of body shape distortion. Tizard Learning Disability Review. 2010;15:15-29.

77. Emerson E. Health status and health risks of the 'hidden majority' of adults with intellectual disability. Intellectual \& Developmental Disabilities. 2011;49:155-65.

78. Kantarcigil C, Sheppard JJ, Gordon AM, Friel KM, Malandraki GA. A telehealth approach to conducting clinical swallowing evaluations in children with cerebral palsy. Research in Developmental Disabilities. 2016;55:207-17.

79. Benfer KA, Weir KA, Bell KL, Ware RS, Davies PSW, Boyd RN. Longitudinal cohort protocol study of oropharyngeal dysphagia: Relationships to gross motor attainment, 
growth and nutritional status in preschool children with cerebral palsy. BMJ Open. 2012;2:0:e001460. doi:10.1136/bmjopen-2012-.

80. Fortunato JE, Darbari A, Cuffari C, Bibat G, Koch K, Desbiens J, Brereton H, Naidu S. Esophageal motility dysfunction in children with Rett syndrome, gastroesophageai reflux, and dysphagia. Journal of Applied Research. 2008;8:84-94.

81. Marriott A, Turner S. Making reasonable adjustments to dysphagia services for people with learning disabilities. Improving Health \& Lives: Learning Disabilities Observatory, http://www.improvinghealthandlives.org.uk/gsf.php5?f=314186\&fv=22099 (accessed 22 August 2016) 2016. 
Table One: Summary of studies relating to dysphagia and people with intellectual disabilities (see bottom of table for list of abbreviations)

\begin{tabular}{|c|c|c|c|c|c|c|c|c|}
\hline $\begin{array}{l}\text { 1st author } \\
\text { \& year }\end{array}$ & Country & Focus & Design & $\begin{array}{l}\text { Key sample features (\% } \\
\text { relating to ID) }\end{array}$ & $\begin{array}{l}\text { Age range } \\
(M(S D) ; M d n)\end{array}$ & $\begin{array}{l}\% \\
\text { male }\end{array}$ & $\begin{array}{l}\text { Sample } \\
\text { size }\end{array}$ & Results \\
\hline $\begin{array}{l}\text { Ayres } \\
2015\end{array}$ & England & $\begin{array}{l}\text { Safety \& efficacy of } \\
\text { PEG placement }\end{array}$ & Retrospective case note audit & Severe ID $(100 \%)$ & $\begin{array}{l}17-63 \\
(37(\mathrm{~ns}) ; \mathrm{ns})\end{array}$ & $48 \%$ & 42 & $\begin{array}{l}117 \text { procedures: } 38 \text { index PEG insertions, } 43 \text { PEG replacements, } 35 \text { PEG-J } \\
\text { replacements \& } 1 \text { PEG removal. Overall } 31 \text { ( } 74 \% \text { ) experienced at least one } \\
\text { complication. } 30 \text { day mortality was zero. Procedure generally safe \& results in } \\
\text { modest weight gain. }\end{array}$ \\
\hline $\begin{array}{l}\text { Bailey } \\
2005\end{array}$ & US & $\begin{array}{l}\text { Efficacy of a multi- } \\
\text { treatment feeding skill \& } \\
\text { mealtime behaviour } \\
\text { intervention }\end{array}$ & $\begin{array}{l}\text { Single-subject multiple treatment } \\
\text { design }\end{array}$ & $\begin{array}{l}\text { Moderate to profound } \\
\text { cognitive disabilities \& } \\
\text { feeding impairments } \\
(100 \%)\end{array}$ & $\begin{array}{l}4-17 \\
(10(5) ; 11)\end{array}$ & $67 \%$ & 9 & $\begin{array}{l}\text { Combined intervention was most effective. Decrease of } 7 \% \text { in feeding skills in } \\
\text { the condition where school staff delivered the intervention, although results } \\
\text { varied across participants }\end{array}$ \\
\hline $\begin{array}{l}\text { Calis } \\
2008\end{array}$ & $\begin{array}{l}\text { Nether- } \\
\text { lands }\end{array}$ & $\begin{array}{l}\text { Dysphagia in children } \\
\text { with severe generalized } \\
\text { CP \& ID }\end{array}$ & $\begin{array}{l}\text { Data collected as part of longitudinal } \\
\text { study on LRTIs }\end{array}$ & $\begin{array}{l}\text { Representative sample } \\
\text { of children with severe } \\
\text { generalized CP \& ID } \\
(100 \%)\end{array}$ & $\begin{array}{l}\text { ns } \\
\text { (8.5 (4.2); ns) }\end{array}$ & $51 \%$ & 166 & $\begin{array}{l}1 \% \text { no dysphagia, } 8 \% \text { mild, } 76 \% \text { moderate to severe, } 15 \% \text { profound. Only } 31 \% \\
\text { of parents of children with moderate to severe dysphagia reported experiencing } \\
\text { feeding problems often/almost always. Dysphagia severity associated with } \\
\text { severity of motor impairment. } 18 / 133(13.5 \%) \text { had recurrent LRTls }\end{array}$ \\
\hline $\begin{array}{l}\text { Chadwick } \\
2009\end{array}$ & England & $\begin{array}{l}\text { Characteristics \& } \\
\text { conditions associated } \\
\text { with dysphagia }\end{array}$ & $\begin{array}{l}\text { Descriptive study using routinely } \\
\text { collected clinical information (both } \\
\text { retrospective \& prospective) }\end{array}$ & $\begin{array}{l}\text { Adults with ID referred } \\
\text { to speech \& language } \\
\text { therapists (SLTs) with } \\
\text { confirmed dysphagia } \\
(100 \%)\end{array}$ & $\begin{array}{l}18-74 \\
(41(14) ; n s)\end{array}$ & $44 \%$ & 99 & $\begin{array}{l}\text { Stage of swallowing affected: oral } 94.1 \% \text {, pharyngeal } 51.5 \% \text {, oesophageal } \\
25.7 \% \text {, more than one stage } 58.4 \% \text {. Aspiration identified in } 47.9 \% \text {, silent } \\
\text { aspiration in } 31.3 \% \text {. Risks reported: } 89.9 \% \text { high risk of asphyxia; } 67.7 \% \text { high } \\
\text { risk of dehydration; \& } 57.6 \% \text { high risk of poor nutritional status. } 39.4 \% \text { had } \\
\text { more than one aspiration-related RTI in previous year. Those who aspirated } \\
\text { significantly more likely to have history of recurrent chest infections }\end{array}$ \\
\hline $\begin{array}{l}\text { Chadwick } \\
2014\end{array}$ & UK & $\begin{array}{l}\text { Current practice when } \\
\text { recommending tastes } \\
\text { for people with ID who } \\
\text { are non-orally fed }\end{array}$ & Survey & $\begin{array}{l}\text { SLTs or dieticians } \\
\text { working with people with } \\
\text { ID }(100 \%)\end{array}$ & ns & ns & $\begin{array}{l}53 \\
\text { SLTs, } \\
2 \text { diet- } \\
\text { icians }\end{array}$ & $\begin{array}{l}78.2 \% \text { had recommended tastes to those enterally fed. Lack of experience \& } \\
\text { being outside of job role were the main reason given for not recommending } \\
\text { tastes }(n=10) \text {. }\end{array}$ \\
\hline $\begin{array}{l}\text { Chadwick } \\
2002\end{array}$ & England & $\begin{array}{l}\text { Carer knowledge of } \\
\text { dysphagia management } \\
\text { strategies }\end{array}$ & $\begin{array}{l}\text { Structured interviews; compared with } \\
\text { written dysphagia management } \\
\text { recommendations }\end{array}$ & $\begin{array}{l}\text { Caregivers of } 40 \text { adults } \\
\text { with ID with dysphagia } \\
\text { (parents \& support staff) } \\
(100 \%)\end{array}$ & $\begin{array}{l}27-75 \\
(48.2(14.6) ; \mathrm{ns})\end{array}$ & $33 \%$ & 46 & $\begin{array}{l}\text { Carers recounted a significantly greater proportion of management strategies } \\
\text { relating to dietary modification \& equipment use compared with positioning } \\
\text { recommendations; demonstrated least knowledge of support, prompting \& } \\
\text { socializing recommendations }\end{array}$ \\
\hline $\begin{array}{l}\text { Chadwick } \\
2003\end{array}$ & England & $\begin{array}{l}\text { Adherence to eating \& } \\
\text { drinking guidelines }\end{array}$ & $\begin{array}{l}\text { Observation, interviews \& review of } \\
\text { medical records }\end{array}$ & $\begin{array}{l}\text { Adults with ID \& } \\
\text { dysphagia (100\%) }\end{array}$ & $\begin{array}{l}19-74 \\
(40.1(13.5) ; n s)\end{array}$ & $55 \%$ & 40 & $\begin{array}{l}\text { Average adherence by caregivers to SLT guidelines was } 76.6 \%(\mathrm{SD}=12.97 \text {, } \\
\text { range }=50 \% \text { to } 100 \%) \text {. Higher scores attained for adherence to guidelines } \\
\text { regarding food/drink consistency }(89.7 \%) \text {, positioning }(89.3 \%), \& \text { utensil use } \\
(79.2 \%) . \text { Lower adherence observed for support, prompting, \& socializing } \\
(64.4 \%) . \text { In } 50 \% \text { of cases, eating \& drinking occurred too fast \& speed in some } \\
\text { cases increased as meal progressed. Generally only one or at most two } \\
\text { swallows occurred prior to presentation of the ensuing bolus }\end{array}$ \\
\hline
\end{tabular}




\begin{tabular}{|c|c|c|c|c|c|c|c|c|}
\hline $\begin{array}{l}1 \text { st author } \\
\text { \& year }\end{array}$ & Country & Focus & Design & $\begin{array}{l}\text { Key sample features (\% } \\
\text { relating to ID) }\end{array}$ & $\begin{array}{l}\text { Age range } \\
(M(S D) ; M d n)\end{array}$ & $\begin{array}{l}\% \\
\text { male }\end{array}$ & $\begin{array}{l}\text { Sample } \\
\text { size }\end{array}$ & Results \\
\hline $\begin{array}{l}\text { Chadwick } \\
2006\end{array}$ & England & $\begin{array}{l}\text { Barriers to caregiver } \\
\text { compliance with eating } \\
\text { \& drinking } \\
\text { recommendations }\end{array}$ & $\begin{array}{l}\text { Qualitative open-ended semi- } \\
\text { structured interviews }\end{array}$ & $\begin{array}{l}\text { Caregivers of adults } \\
\text { with ID \& dysphagia } \\
\text { (parents \& support staff) } \\
(100 \%)\end{array}$ & $\begin{array}{l}27-75 \\
(48.2(14.6) ; n s)\end{array}$ & $33 \%$ & 46 & $\begin{array}{l}\text { Consistency recommendations caused concern (22 statements), including } \\
\text { worry about achieving correct safe consistency (12) \& conflict between safe } \\
\text { consistency \& diet person actually wants (6). Additional barriers included time } \\
\text { pressures, staff turnover \& insufficient reviewing of SLT management strategies } \\
\text { by caregivers. Some parents gave indirect evidence that dysphagia guidelines } \\
\text { had not altered their method of giving meals \& drinks }\end{array}$ \\
\hline $\begin{array}{l}\text { Chadwick } \\
2014\end{array}$ & England & $\begin{array}{l}\text { Efficacy of training staff } \\
\text { to modify fluids to } \\
\text { appropriate } \\
\text { consistencies }\end{array}$ & $\begin{array}{l}\text { Pre-post experimental design with } 3 \\
\text { groups: written guidance; typical } \\
\text { training; \& typical training with } \\
\text { Thickness Indicator Model (TIM) tubes }\end{array}$ & $\begin{array}{l}\text { Support staff for adults } \\
\text { with ID; no prior } \\
\text { experience of modifying } \\
\text { fluid consistencies } \\
(100 \%)\end{array}$ & $\begin{array}{l}19-64 \\
(41.3(12.8) ; n s)\end{array}$ & $31 \%$ & 62 & $\begin{array}{l}\text { At 3-10-month follow-up only the group who received typical training alongside } \\
\text { the TIM tubes were significantly more accurate than the Written Guidance } \\
\text { group }\end{array}$ \\
\hline $\begin{array}{l}\text { Crawford } \\
2007\end{array}$ & England & $\begin{array}{l}\text { Carer compliance with } \\
\text { dysphagia management } \\
\text { recommendations }\end{array}$ & $\begin{array}{l}\text { Observation of meal \& questionnaire } \\
\text { completed by carer }\end{array}$ & $\begin{array}{l}\text { Carers in day centre } \\
\text { supporting } 27 \text { adults } \\
\text { with ID \& dysphagia } \\
(100 \%)\end{array}$ & ns (for carers) & $15 \%$ & 27 & $\begin{array}{l}77.8 \% \text { carers were aware that client had eating \& drinking recommendations, } \\
66.7 \% \text { had any training in eating \& drinking. Overall compliance } 82 \% \text {, lowest } \\
(64 \%) \text { for appropriate utensils. } 100 \% \text { with direct support recommendations Non- } \\
\text { compliance sometimes due to difficulties getting suitable foods from kitchen }\end{array}$ \\
\hline $\begin{array}{l}\text { Field } \\
2003\end{array}$ & US & $\begin{array}{l}\text { Feeding problems in } \\
\text { children referred to a } \\
\text { feeding clinic }\end{array}$ & Retrospective review of records & $\begin{array}{l}\text { Children with Down } \\
\text { syndrome (DS) }(100 \%)\end{array}$ & ns & ns & 21 & $\begin{array}{l}82 \% \text { had oral motor delays, } 36 \% \text { had dysphagia, many ate only pureed or low- } \\
\text { textured food \& refused to chew, despite having the ability to chew }\end{array}$ \\
\hline $\begin{array}{l}\text { Frazier } \\
1996\end{array}$ & US & $\begin{array}{l}\text { Swallow function in } \\
\text { children with Down } \\
\text { syndrome }\end{array}$ & Retrospective chart review & $\begin{array}{l}\text { Children with DS } \\
\text { referred to a swallowing } \\
\text { disorders clinic }(100 \%)\end{array}$ & $\begin{array}{l}0.25-4 \\
(2(\mathrm{~ns}) ; \mathrm{ns})\end{array}$ & $84 \%$ & 19 & $\begin{array}{l}84.2 \% \text { had oral hypotonia. } 52.6 \% \text { aspirated during VMBS, } 6 \text { on thin liquid, } 2 \text { on } \\
\text { thickened liquid, \& } 2 \text { on both. Of } 8 \text { children who aspirated on thin liquid, } 5 \text { had } \\
\text { safe swallow when texture modified to thickened liquid. Of } 4 \text { who aspirated } \\
\text { thickened liquid, } 3 \text { had safe swallow when texture was modified to puree (one } \\
\text { was not given puree as only } 3 \text { months old). Of } 10 \text { children who aspirated, } 5 \\
\text { were referred due to recurrent pneumonia. Of } 10 \text { who aspirated, cough data } \\
\text { was available for } 8 \text { \& all were silent aspirators }\end{array}$ \\
\hline $\begin{array}{l}\text { Freeman } \\
2003\end{array}$ & US & $\begin{array}{l}\text { Availability \& delivery of } \\
\text { speech-language } \\
\text { services for adults with } \\
\text { ID in South-Eastern } \\
\text { Ontario }\end{array}$ & Telephone survey & $\begin{array}{l}\text { Staff of developmental } \\
\text { service agencies or } \\
\text { SLPs }(100 \%)\end{array}$ & ns & ns & $>40$ & $\begin{array}{l}\text { Swallowing assessments (videofluoroscopic \& bedside) are available but direct } \\
\text { treatment, staff training, \& follow up services are limited. Staffing changes \& } \\
\text { turnover rates impact negatively on feeding/swallowing strategies for clients. } \\
\text { Once a client met therapeutic goals services of the SLP were removed \& } \\
\text { implementation of program often discontinued. }\end{array}$ \\
\hline $\begin{array}{l}\text { Gittins } \\
2008\end{array}$ & England & $\begin{array}{l}\text { Dysphagia in adults } \\
\text { with PMLD }\end{array}$ & Cross-sectional (audit) & $\begin{array}{l}\text { Adults with PMLD } \\
(100 \%)\end{array}$ & $\begin{array}{l}18-51+ \\
(37(\mathrm{~ns}) ; \mathrm{ns})\end{array}$ & ns & 61 & $\begin{array}{l}\text { Prevalence } 29.5 \% \text {; there was no funding for a dysphagia service for adults with } \\
\text { learning disabilities within the health trust, audit provided evidence of need for a } \\
\text { service which was subsequently provided }\end{array}$ \\
\hline $\begin{array}{l}\text { Gray } \\
2006\end{array}$ & US & $\begin{array}{l}\text { Pneumonia before \& } \\
\text { after enteral tube } \\
\text { feeding }\end{array}$ & $\begin{array}{l}\text { Retrospective review of clinical } \\
\text { records }\end{array}$ & $\begin{array}{l}\text { People ( } 89 \% \text { profound } \\
\text { ID) who had feeding } \\
\text { tube placed \& } \\
\text { pneumonia in year prior } \\
(100 \%)\end{array}$ & ns & $51 \%$ & 93 & $\begin{array}{l}\text { In the year prior tube insertion there were } 75 \text { episodes of pneumonia in } 49 \\
\text { people. In the year after there were } 41 \text { episodes in } 26 \text { people (significant } 45 \% \\
\text { decrease in pneumonia) }\end{array}$ \\
\hline $\begin{array}{l}\text { Guthrie } \\
2015\end{array}$ & England & $\begin{array}{l}\text { Carer perceptions of } \\
\text { influences on choking at } \\
\text { evening meal }\end{array}$ & Qualitative semi-structured interviews & $\begin{array}{l}\text { Staff involved in choking } \\
\text { incidents at specialist } \\
\text { secure ID service } \\
(100 \%)\end{array}$ & ns & ns & 5 & $\begin{array}{l}\text { No references made to dysphagia, comments emphasized service user } \\
\text { behaviour \& social \& environmental aspects of mealtimes. Perceived need for } \\
\text { increased staffing \& staff familiar with residents at evening meals. Incidents } \\
\text { described as 'scariest' \& 'most frightening' }\end{array}$ \\
\hline Guthrie & England & Choking incident & Retrospective review of 2010 choking & Local specialist secure & $28-74 \mathrm{~L}$ & $70 \% \mathrm{~L}$ & $47 \mathrm{~L}$ & 6 subthemes identified relating to staff perceptions of factors influencing the risk \\
\hline
\end{tabular}




\begin{tabular}{|c|c|c|c|c|c|c|c|c|}
\hline $\begin{array}{l}1^{\text {st }} \text { author } \\
\text { \& year }\end{array}$ & Country & Focus & Design & $\begin{array}{l}\text { Key sample features (\% } \\
\text { relating to ID) }\end{array}$ & $\begin{array}{l}\text { Age range } \\
(M(S D) ; M d n)\end{array}$ & $\begin{array}{l}\% \\
\text { male }\end{array}$ & $\begin{array}{l}\text { Sample } \\
\text { size }\end{array}$ & Results \\
\hline 2015 & & reporting & reports & $\begin{array}{l}\text { ID service }(L) \text { \& } \\
\text { nationally }(N) \text { : people in } \\
\text { ID or mental health care } \\
\text { settings }(\mathrm{L} 100 \% ; \mathrm{N} \mathrm{ns})\end{array}$ & ns N & ns N & $436 \mathrm{~N}$ & $\begin{array}{l}\text { of choking: care pathway; time of day ( } 40 \% \text { of local incidents were at evening } \\
\text { meal); food types; medication (including antipsychotic side effects); behaviours } \\
\text { (e.g. cramming or rushing food); \& familiarity of staff. Potential for heightened } \\
\text { risk associated with unfamiliar staff }\end{array}$ \\
\hline $\begin{array}{l}\text { Harding } \\
2009\end{array}$ & England & $\begin{array}{l}\text { Staff training on } \\
\text { dysphagia }\end{array}$ & Pre- post- questionnaire & $\begin{array}{l}\text { Staff working (including } \\
\text { mealtimes) with children } \\
\text { age 2-11 years with } \\
\text { PMLD within specialist } \\
\text { educational provision } \\
(100 \%)\end{array}$ & ns & ns & 23 & $\begin{array}{l}\text { Pre-training some staff: unsure about how to mix thickeners \& modify textures } \\
\text { correctly; considered giving occasional snack foods such as wotsits to someone } \\
\text { on soft diet would not cause risk; believed you could continue to feed someone } \\
\text { coughing repeatedly as it means they can swallow safely; lacked understanding } \\
\text { of relationship of positioning to the safety of eating \& drinking. Significant } \\
\text { improvement in all these areas post training \& in confidence regarding } \\
\text { thickening liquids, positioning, \& understanding of SLT strategies }\end{array}$ \\
\hline $\begin{array}{l}\text { Hennequin } \\
2015\end{array}$ & France & $\begin{array}{l}\text { Effect of increasing } \\
\text { inter-arch contacts } \\
\text { using an occlusal } \\
\text { orthotic appliance for } \\
\text { the mandibular arch on } \\
\text { masticatory efficiency }\end{array}$ & $\begin{array}{l}\text { Prospective longitudinal controlled \& } \\
\text { nonrandomised (quasi-experimental) } \\
\text { trial }\end{array}$ & $\begin{array}{l}\text { Adults with DS attending } \\
\text { for dental consultation; } \\
\text { (control group } 12 \\
\text { healthy fully dentate } \\
\text { young adults) (treatment } \\
\text { group 100\%) }\end{array}$ & $\begin{array}{l}\mathrm{ns} \\
(28.5(9.3) ; \mathrm{ns})\end{array}$ & $29 \%$ & $\begin{array}{l}14 \text { DS; } \\
12 \\
\text { control } \\
\text { group }\end{array}$ & $\begin{array}{l}\text { In the DS group, increasing the number of posterior functional units (PFUs) led } \\
\text { to a decrease in bolus particle size, to fewer masticatory cycles needed to } \\
\text { produce a bolus ready for swallowing \& to a decrease in the occurrence of food } \\
\text { refusal, while mean chewing frequency did not vary }\end{array}$ \\
\hline $\begin{array}{l}\text { Kennedy } \\
1997\end{array}$ & Scotland & Nutrition & $\begin{array}{l}\text { Anthropometric surveys; monitoring of } \\
\text { interventions }\end{array}$ & $\begin{array}{l}\text { Children \& adults at } \\
\text { large hospital for people } \\
\text { with ID }(\mathrm{H}) \text { or those } \\
\text { living in community (C) } \\
(100 \%)\end{array}$ & ns & $55 \%$ & $\begin{array}{l}318 \mathrm{H} \\
99 \mathrm{C}\end{array}$ & $\begin{array}{l}\text { Over } 60 \% \text { were underweight due to swallowing difficulties. Fluid programme } \\
\text { aimed at providing } 2.5 \text { litres a day for those with nutrition or dysphagia } \\
\text { disorders led to immediate fall in acute hospital admissions with hypematraemic } \\
\text { dehydration. For } 40 \text { patients with PEG tubes monitored over a median of } 102 \\
\text { weeks, median weight rose by } 31 \% \text {, median } \% \text { body fat by } 82 \%\end{array}$ \\
\hline $\begin{array}{l}\text { Lee } \\
2010\end{array}$ & Australia & $\begin{array}{l}\text { Experience \& outcomes } \\
\text { of PEG feeding }\end{array}$ & $\begin{array}{l}\text { Audit based on medical files, } \\
\text { observations of current status, \& } \\
\text { open-ended interviews with families, } \\
\text { nurses \& GPs }\end{array}$ & $\begin{array}{l}\text { People with severe to } \\
\text { profound ID PEG fed } \\
\text { mean } 8.5 \text { yrs (range } 1 \text { - } \\
\text { 18) }(100 \%)\end{array}$ & $\begin{array}{l}15-40 \\
(27(\mathrm{~ns}) ; \mathrm{ns})\end{array}$ & $50 \%$ & 40 & $\begin{array}{l}10 \text { had died since initiation of PEG feeding, pneumonia terminal event in all. Of } \\
26 \text { underweight at initiation, } 17 \text { gained some weight; } 11 \text { who had had their } \\
\text { community activities curtailed because of frequent illness were able to return to } \\
\text { activities after PEG feeding, two thirds were unable to return to pre-PEG } \\
\text { community activities }\end{array}$ \\
\hline $\begin{array}{l}\text { McCarron } \\
2010\end{array}$ & Ireland & $\begin{array}{l}\text { Challenges \& care } \\
\text { concerns of staff carers } \\
\text { of people with DS \& } \\
\text { advanced dementia }\end{array}$ & Focus groups & $\begin{array}{l}\text { Staff carers of people } \\
\text { with DS \& advanced } \\
\text { dementia }(100 \%)\end{array}$ & ns & ns & 57 & $\begin{array}{l}\text { One theme to emerge was fear of swallowing difficulties with participants } \\
\text { speaking about the 'fear' of feeding individuals with swallowing difficulties \& the } \\
\text { anxiety it generated }\end{array}$ \\
\hline $\begin{array}{l}\text { O'Neill } \\
2013\end{array}$ & US & $\begin{array}{l}\text { Pharyngeal dysphagia } \\
(P D) \text { in children with DS }\end{array}$ & $\begin{array}{l}\text { Retrospective chart review, } \\
\text { documented VFSS used to establish } \\
\text { diagnosis of PD }\end{array}$ & $\begin{array}{l}\text { Children with DS } \\
\text { attending tertiary care } \\
\text { hospital }(100 \%)\end{array}$ & $\begin{array}{l}0.4-24.7 \\
(7.5(\mathrm{~ns}) ; \mathrm{ns})\end{array}$ & $51 \%$ & 201 & $\begin{array}{l}116(57.7 \%) \text { had had PD, \& of these } 27.6 \% \text { had comorbid pulmonary conditions } \\
\text { such as recurrent pneumonia \& bronchitis. PD often persisted despite surgical } \\
\text { intervention for upper airway obstruction }\end{array}$ \\
\hline $\begin{array}{l}\text { Perez } \\
2015\end{array}$ & England & $\begin{array}{l}\text { Healthcare use, ill } \\
\text { health \& mortality in } \\
\text { adults with ID \& } \\
\text { mealtime support needs }\end{array}$ & $\begin{array}{l}\text { Cohort study with two surveys, } \\
\text { administered } 1 \text { year apart }\end{array}$ & $\begin{array}{l}\text { Adults known to ID } \\
\text { services in two counties } \\
\text { who required support for } \\
\text { any problem with eating, } \\
\text { drinking or swallowing } \\
\text { (EDS) }(100 \%)\end{array}$ & $\begin{array}{l}18-90 \\
(46.6(17.7) ; 47)\end{array}$ & $55 \%$ & $\begin{array}{l}127 \\
\text { survived } \\
8 \text { died }\end{array}$ & $\begin{array}{l}22 / 36(61.1 \%) \text { of those with CP had diagnosed dysphagia, compared with } 5 / 18 \\
(27.8 \%) \text { of those with DS and } 18 / 71(25.4 \%) \text { of those with unknown or other } \\
\text { aetiologies. Each year, most visited their GP at least once \& in year one around } \\
20 \% \text { attended hospital for any emergency reason. Around one in five GP \& } \\
\text { emergency hospital visits were for EDS problems. Around one third of } \\
\text { participants had a respiratory infection in each year and } 26 / 122(21.3 \%) \text { had } \\
\text { respiratory infections in both years. For those who saw the GP for an EDS- }\end{array}$ \\
\hline
\end{tabular}




\begin{tabular}{|c|c|c|c|c|c|c|c|c|}
\hline $\begin{array}{l}1 \text { st author } \\
\text { \& year }\end{array}$ & Country & Focus & Design & $\begin{array}{l}\text { Key sample features (\% } \\
\text { relating to ID) }\end{array}$ & $\begin{array}{l}\text { Age range } \\
(M(S D) ; M d n)\end{array}$ & $\begin{array}{l}\% \\
\text { male }\end{array}$ & $\begin{array}{l}\text { Sample } \\
\text { size }\end{array}$ & Results \\
\hline & & & & & & & & $\begin{array}{l}\text { related problem, the primary cause was respiratory infections in both year one } \\
47 / 58(81.0 \%) \text { \& year } 230 / 38(78.9 \%) \text {. Respiratory infections were also the } \\
\text { most common single reason for EDS-related emergency hospitalizations in year } \\
2 \text {, accounting for } 9 / 21(43 \%) \text { of which } 4 \text { were specifically for aspiration } \\
\text { pneumonia. There were nutritional concerns for } 20 / 127(15.7 \%) \text { in year one } \\
\text { and } 13 / 124(10.5 \%) \text { in year two. Almost three times as many participants died } \\
\text { as would be expected in the 'general' ID population (SMR } 267 \text { (exact } 95 \% \mathrm{Cl} \\
115-526) \text { ). Respiratory infections were the immediate cause of death in all } \\
\text { eight cases }\end{array}$ \\
\hline $\begin{array}{l}\text { Rogers } \\
1994 a\end{array}$ & US & $\begin{array}{l}\text { Characteristics of } \\
\text { dysphagia in children } \\
\text { with } \mathrm{CP}\end{array}$ & $\begin{array}{l}\text { Retrospective review of clinical } \\
\text { evaluations \& VMBS studies }\end{array}$ & $\begin{array}{l}\text { Children with CP \& } \\
\text { dysphagia (93\%) }\end{array}$ & $\begin{array}{l}1 \text { wk-22yrs } \\
\text { (7.5 (ns); ns) }\end{array}$ & $54 \%$ & 90 & $\begin{array}{l}37.8 \% \text { aspirated, } 18.9 \% \text { prior to or during swallowing, } 18.9 \% \text { after swallowing; } \\
\text { almost all both oral \& pharyngeal abnormalities. Aspiration silent in } 97 \% \text { of } \\
\text { those who aspirated }\end{array}$ \\
\hline $\begin{array}{l}\text { Rogers } \\
1994 b\end{array}$ & US & $\begin{array}{l}\text { Clinical \& radiographic } \\
\text { features of dysphagia \& } \\
\text { long-term complications } \\
\text { of aspiration }\end{array}$ & $\begin{array}{l}\text { Clinical examination \& review of } \\
\text { medical records }\end{array}$ & $\begin{array}{l}\text { Adults referred to } \\
\text { feeding disorders clinic, } \\
90 \% \text { profound ID. } \\
\text { Aspiration group (A), no } \\
\text { aspiration group (NA). } \\
(100 \%)\end{array}$ & $\begin{array}{l}\text { A } 14-75 \\
(41.5 \text { (ns); ns) } \\
\text { NA } 24-69 \\
(42.0 \text { (ns); ns) }\end{array}$ & $51 \%$ & 67 & $\begin{array}{l}29.9 \% \text { aspirated. } 70 \% \text { of A group had a history of respiratory distress during } \\
\text { meals or history of chronic lung disease, } 35 \% \text { of A group on benzodiazepans or } \\
\text { phenothiazines. Significant differences between A/NA groups in airway } \\
\text { management concerns during oral feedings ( } 65 \% \text { vs. } 23 \%), \& \text { chronic lung } \\
\text { disease ( } 55 \% \text { vs. } 4 \% \text { ). In A group those dependent on others for oral feedings } \\
\text { had highest risk of chronic lung disease }\end{array}$ \\
\hline $\begin{array}{l}\text { Samuels } \\
2006\end{array}$ & England & $\begin{array}{l}\text { Predictors of } \\
\text { asphyxiation risk }\end{array}$ & Retrospective review of records & $\begin{array}{l}\text { Adults with ID identified } \\
\text { as having dysphagia by } \\
\text { speech therapy services } \\
(100 \%)\end{array}$ & $\begin{array}{l}17-74 \\
(42.2(14.5) ; n s)\end{array}$ & $50 \%$ & 80 & $\begin{array}{l}\text { Variables predictive of asphyxiation risk included maladaptive eating strategies } \\
\text { of cramming \& speed of eating } \& \text { the physiological factor of premature loss of } \\
\text { the bolus into the pharynx. For } 58 / 80 \text { participants where incident reports kept, } \\
70.7 \% \text { had near fatal choking incident in last year }\end{array}$ \\
\hline $\begin{array}{l}\text { Santoro } \\
2012\end{array}$ & Italy & $\begin{array}{l}\text { A multi-disciplinary } \\
\text { approach for identifying } \\
\text { feeding abnormalities }\end{array}$ & $\begin{array}{l}\text { Protocol: examination by } \\
\text { developmental neuropsychiatrist; } \\
\text { assessment by speech pathologist; } \\
\text { clinical otorhinolaryngoiatric } \\
\text { examination. Also VMBS }\end{array}$ & $\begin{array}{l}\text { Children with CP \& ID } \\
\text { with feeding problems } \\
(100 \%)\end{array}$ & $\begin{array}{l}0.3-11.3 \\
(3.2(n s) ; n s)\end{array}$ & $65 \%$ & 40 & $\begin{array}{l}\text { Comprehensive multidisciplinary evaluation and mealtime observation was } \\
\text { appropriate for proactive identification of indicators of dysphagia in children with } \\
\text { CP \& ID with feeding problems. Aspiration identified via radiography in } 7 \\
(17.5 \%)\end{array}$ \\
\hline $\begin{array}{l}\text { Sheehan } \\
2016\end{array}$ & $\begin{array}{l}\text { England } \\
\& \text { Wales }\end{array}$ & Quality of inpatient care & Case-note audit & $\begin{array}{l}\text { Adult acute general or } \\
\text { mental health service } \\
\text { inpatients with ID } \\
(100 \%)\end{array}$ & $\begin{array}{l}\text { ns } \\
(43(16.9) ; n s)\end{array}$ & $52 \%$ & 176 & $\begin{array}{l}\text { Swallowing assessment received in actual general services by } 31 / 109(28.4 \%) \text {, } \\
\text { mental health services } 3 / 67(4.5 \%) \text {, overall } 34 / 176(19.3 \%)\end{array}$ \\
\hline $\begin{array}{l}\text { Smith } \\
2014\end{array}$ & $\begin{array}{l}\text { Singa- } \\
\text { pore }\end{array}$ & $\begin{array}{l}\text { Oral feeding in adults } \\
\text { with DS }\end{array}$ & $\begin{array}{l}\text { Observational study: videotape of one } \\
\text { mealtime for each participant }\end{array}$ & $\begin{array}{l}\text { Adults with DS with no } \\
\text { reported EDS difficulties } \\
(100 \%)\end{array}$ & $\begin{array}{l}22-50 \\
(41.3(7.76) ; n s)\end{array}$ & $43 \%$ & 23 & $\begin{array}{l}\text { Despite having no reported EDS difficulties, oral phase difficulties were } \\
\text { observed in majority \& coughing on food and/or drink (a possible sign of } \\
\text { aspiration) in } 56.5 \%\end{array}$ \\
\hline $\begin{array}{l}\text { Thacker } \\
2008\end{array}$ & England & Risk factors for choking & $\begin{array}{l}\text { Postal survey of carers \& in-depth } \\
\text { interviews with subsample of } 18 \\
\text { carers where serious or unusual } \\
\text { choking history }\end{array}$ & $\begin{array}{l}\text { Adults with ID registered } \\
\text { with two local authorities } \\
(100 \%)\end{array}$ & $\begin{array}{l}16-50+ \\
\text { (ns (ns); ns) }\end{array}$ & $49 \%$ & 674 & $\begin{array}{l}40.5 \% \text { reported one or more choking events. DS diagnosis (OR } 1.60(95 \% \mathrm{Cl} \\
1.08,2.35)) \text {, needing help with liquids (OR } 4.46(1.74,11.46)) \text {, inability to read } \\
\text { (OR } 1.40(1.01,1.95)) \text { \& being on tranquillizers (OR } 1.89(1.21,2.94)) \\
\text { associated with an increase in the odds of choking }\end{array}$ \\
\hline $\begin{array}{l}\text { Tredinnick } \\
2013\end{array}$ & England & $\begin{array}{l}\text { One day dysphagia } \\
\text { training for support } \\
\text { workers }\end{array}$ & $\begin{array}{l}\text { Repeated measures (before, after, } \\
\text { one month after) with control group }\end{array}$ & $\begin{array}{l}\text { Support workers for } \\
\text { adults with ID }(100 \%)\end{array}$ & ns & ns & $\begin{array}{l}25 \\
\text { training } \\
13 \\
\text { control }\end{array}$ & $\begin{array}{l}\text { Trained group gained in knowledge \& confidence \& gain maintained a month } \\
\text { after training. High confidence \& low knowledge scores in the control group } \\
\text { may mean that this staff group may be putting clients at risk due to not } \\
\text { recognising or underestimating problems }\end{array}$ \\
\hline Waterman & US & Swallowing disorders in & Retrospective review of medical & Children with CP (89\%) & $5-21$ & ns & 56 & $26.8 \%$ dysphagia \& $\%$ increased with level of ID. Of 15 with dysphagia: $33 \%$ \\
\hline
\end{tabular}




\begin{tabular}{|c|c|c|c|c|c|c|c|c|}
\hline $\begin{array}{l}1 \text { st author } \\
\& \text { year }\end{array}$ & Country & Focus & Design & $\begin{array}{l}\text { Key sample features (\% } \\
\text { relating to ID) }\end{array}$ & $\begin{array}{l}\text { Age range } \\
(M(S D) ; M d n)\end{array}$ & $\begin{array}{l}\% \\
\text { male }\end{array}$ & $\begin{array}{l}\text { Sample } \\
\text { size }\end{array}$ & Results \\
\hline 1992 & & children with $\mathrm{CP}$ & records & & (ns (ns); 14) & & & $\begin{array}{l}\text { aspirated; } 53.3 \% \text { had a history of pneumonia \& more frequent episodes than } \\
\text { those without ( } 1-2 \text { episodes } 26.7 \% \text { vs. } 9.8 \%, 3 \text { or more episodes } 26.7 \% \text { vs. } \\
7.3 \%) ; 80 \% 2+\text { episodes of choking in } 3 \text { months (vs. } 0 \% \text { for those without) }\end{array}$ \\
\hline
\end{tabular}

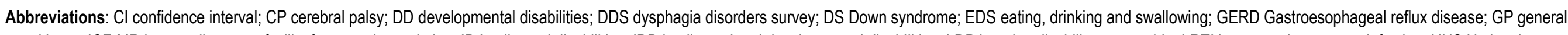

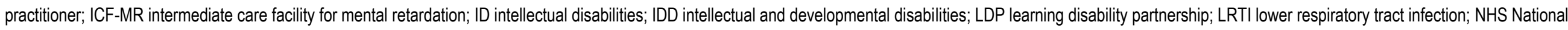

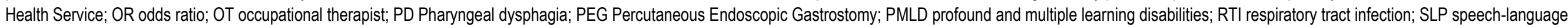
pathologist; SLT speech and language therapist; STEP Screening Tool of fEeding Problems; VFSS videofluoroscopic swallow study; VMBS videofluoroscopic modified barium swallow. 
Dysphagia Research Review 